\title{
Degraded forest lands and pine plantations in homogeneous ecological areas in Mexico
}

\author{
Flores, A. ${ }^{*}$; Méndez-González, J. ${ }^{2}$; Muñoz-Flores, H.J. ${ }^{3}$ \\ ${ }^{1}$ INIFAP, Centro Nacional de Investigación Disciplinaria en Conservación y Mejoramiento de Ecosistemas \\ Forestales, Av. Progreso \#5, Colonia Barrio de Santa Catarina, Coyoacán, Cuidad de México. \\ ${ }^{2}$ Universidad Autónoma Agraria Antonio Narro, Departamento Forestal. Saltillo, Coahuila, México. \\ ${ }^{3}$ INIFAP, Campo Experimental Uruapan. Av. Latinoamericana \#1101, Col. Revolución, Uruapan, \\ Michoacán. \\ * Corresponding author: flores.andres@inifap.gob.mx
}

Citation: Flores, A., Méndez-González, J., \& Muñoz-Flores, H.J. (2021). Degraded forest lands and pine plantations in homogeneous ecological areas in Mexico. Agro Productividad, 14(\#). https://doi. org/10.32854/agrop.v14i7.1911

Editor in Chief: Dr. Jorge Cadena Iñiguez

Estimated publication date: August 2021

This work is licensed under a Creative Commons Attribution-Non-Commercial 4.0 International license.

\section{$(1)$}

\begin{abstract}
Objectives: i) to determine the total degraded areas of EZ in the country, ii) estimate the priority degraded areas for restoration planting, and iii) assess the species and planted areas of the Pinus genus and whether these were within their natural distribution range.

Design/methodology/approach: total EZ degradation surfaces and priority degraded areas for restoration plantings were determined with the Germplasm Movement Zones and Restoration Zones of the Comisión Nacional Forestal (National Forestry Commission, CONAFOR), while planted surfaces were estimated from the CONAFOR records from 2016 to 2018.

Results: on degradation, it was shown that three EZ had large areas, six EZ intermediate areas and 32 EZ small areas; two degradation types (III.C and III.D) were prioritized and viable for restoration plantings; four species $(23 \%)$ were established outside their natural distribution range while ten $(59 \%)$ were within it, three species were undefined.

Study limitations/implications: for restoration of areas, it is necessary to avoid high initial plant mortality and poor growth.

Findings/conclusions: the north of the country has larger areas with degradation, while the center, north and south have areas with medium and low degradation; planting species outside their distribution range leads to plant adaptation problems.
\end{abstract}

Keywords: temperate forests, soil conservation, forest restoration.

\section{INTRODUCTION}

Globally, temperate forests occupy about a quarter of the world's forests and are present to a great extent in the United States and southern Canada, Europe, China, and Australia (Gorte \& Sheikh, 2010); however, the areas of this ecosystem type are still decreasing due to deforestation. The common cause of disturbance in developing countries is the land conversion to non-agricultural uses, commercial, residential developments and infrastructure construction such as roads (Flores, Velasco-García et al., 2018; Stein et al., 2005). Other agents reducing the area of this type of ecosystem are the uncontrolled timber harvest and natural disasters, both of which promote the opening of extensive areas 
where reforestation has little success, due to survivorship problems related to drought and competing species invasion (native shrubs, exotic species) (Gorte \& Sheikh, 2010).

In Mexico, temperate forests occupy an area of approximately $17 \%$ of the country (323 $305 \mathrm{~km}^{2}$ ) and provide timber and non-timber resources (Galicia et al., 2015). However, these ecosystems have been reduced due to increased land degradation, which, according to studies and official reports, the national projections of deforestation rate vary from 260000 to 1600000 ha year $^{-1}$ the last three decades (Couturier et al., 2012). The government has responded to this situation through nationwide reforestation and soil conservation programs managed by the Comisión Nacional Forestal (National Forestry Commission). However, despite this efforts, the current low percentage of seedling survival (36\%) is a problem (Wallace et al., 2015), associated with inadequate plant quality and erroneous species location in areas outside their natural distribution range.

Land degradation is a problem increasing the number of people in poverty (Boer $e t$ $a l ., 2017)$ and is linked to food insecurity and vulnerability to climate change (Barbier \& Hochard, 2016). Although the assessment of forest land degradation at the Homogeneous Ecological Zones (EZ) level has not been conducted to assess the effect it has had on forests in Mexico.

A EZ is an area with extensive formations of natural vegetation, but relatively homogeneous, with similar physiognomy although not necessarily identical (Food and Agriculture Organization [FAO], 2001). A viable example of these homogeneous ecological areas are the Germplasm Movement Zones, which have similar conditions for the forest species development and have superior to the conventional operational management (local, state or Umafor). Evaluating the EZ degree of degradation is a key element for planning the resources restoration, based on the adequate establishment of trees from the regions they come from.

Forest plantations in Mexico have a high potential to increase their production (Flores, Muñoz-Gutiérrez et al., 2018) and the recover deteriorated areas. A large part of the established areas has been made with fast-growing trees for timber, and in few states: Tabasco, Veracruz, Campeche, Chiapas and Puebla (Conafor, 2014). In this regard, it is necessary to increase the number of species for the restoration of degraded areas, particularly in regions with temperate climates where conifers prevail (Flores et al., in press). This will contribute to land recovery, carbon sequestration, and ecosystems and biodiversity preservation. Based on the above and with the purpose of assessing the degraded areas of forest land and the areas planted with pine in EZ, the objective here was to determine the total degraded areas of EZs in Mexico, estimating the priority degraded areas for restoration plantations in EZs, and to identify areas planted with species of the Pinus genus within their natural distribution range.

\section{MATERIALS AND METHODS}

To determine the total degradation surfaces of the EZs, Germplasm Movement Zones (GMZ) and Restoration Zones (RZ), both made by the National Forestry Commission (CONAFOR, 2016, 2017b), were used (Figure 1 and 2). The GMZ are areas with similar ecological and climatic characteristics that host populations with relatively uniform 
genotypes or phenotypes (Flores et al., 2014), that reduce the movement of germplasm out of its natural distribution; while the RZ correspond to forest areas with evidence of degradation, in different degrees, and that constitute a risk due the loss of the forest resource (SEMARNAT, 2015). It was proposed to use GMZ as EZs because they are homogeneous areas in terms of climate and latitudinal or longitudinal distribution (Conafor, 2016). The RZs were used because they consider five types of forest land degradation for the country: forest land with high soil degradation (III.A); forest land with severe erosion (III.B); forest land with medium degradation (III.C); forest land with low degradation (III.D); and degraded forest land with management for restoration (III.E). The processing of the GMZ and RZ, and the information representation was carried out using the QGIS software (http://qgis.osgeo.org) (QGIS Development Team, 2015).

The definition of priority degraded areas for restoration plantations was made considering only two types of forest land degradation: III.C and III.D, due to their moderate degree of deterioration (medium and low) (Flores et al., 2019). Degraded areas (ha) were estimated, and the percentages that these represent in the EZs and in the country following the formulas (1 and 2) proposed:

$$
\% D_{E Z}=\frac{A D Z}{A T D} * 100
$$

Where: $\% D_{E Z}=$ Percentage type III.C or III.D degradation in Homogeneous Ecological Zones. $A D Z=$ Degraded area (ha) type III.C or III.D in the Homogeneous Ecological Zones. $A T D=$ Total degraded area (ha) of all types (III.A to III.E) in the Homogeneous Ecological Zones.

$$
\% D_{P}=\frac{A D Z}{A T D P} * 100
$$

Where: $\% D_{P}=$ Percentage type III.C or III.D degradation in the country. $A D Z=$ Degraded area (ha) type III.C or III.D in the Homogeneous Ecological Zones. ATDP=Total degraded area (ha) of all types (III.A to III.E) in the country.

To estimate the planted areas with species of the Pinus genus within its natural distribution range, CONAFOR records for the last three years (2016 to 2018) were used, which are an indicator of the areas in which this work has been done in Mexico. Due to the annual variation of the areas, the average for the analyzed period was calculated. Likewise, it was determined whether these conifers were established in the states that comprise the natural distribution range of the species by EZ. This distribution was determined based on the geographic data (latitude and longitude) of the plots of the National Forest and Soil Inventory 2004-2007 (CONAFOR, 2017a), its representation was done with the QGIS program (http://qgis.osgeo.org) (QGIS Development Team, 2015). 


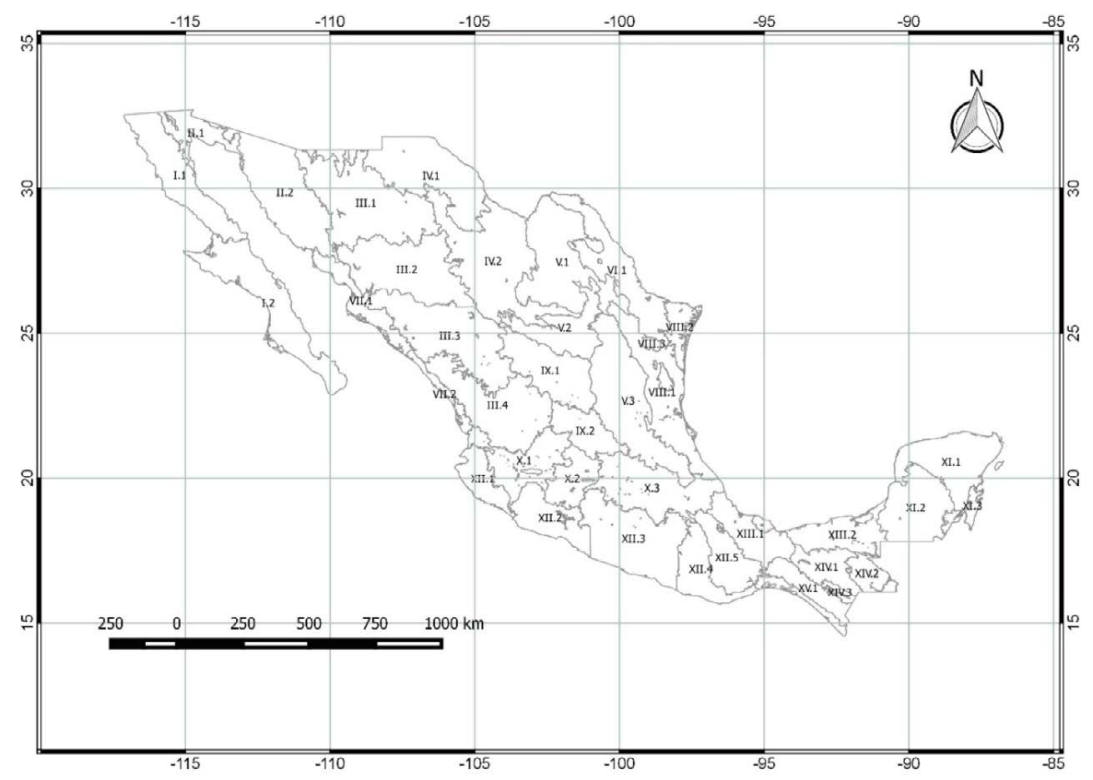

Figure 1. Germplasm Movement Zones of Mexico.

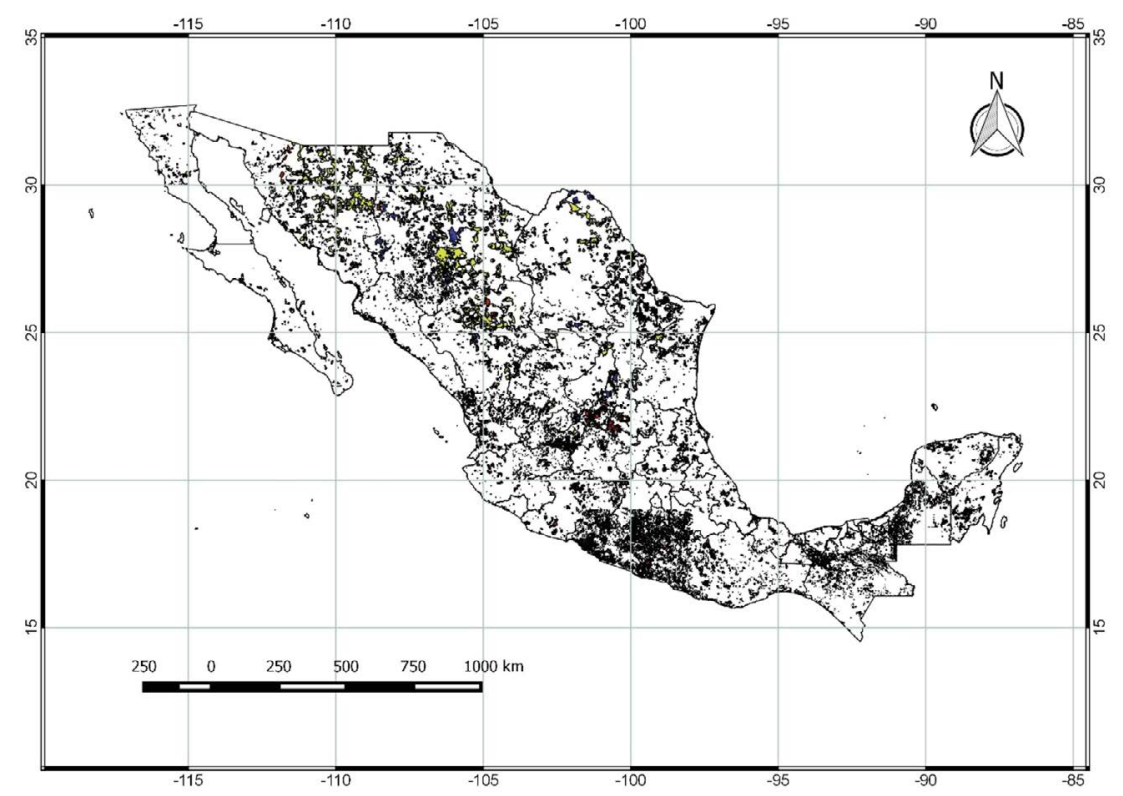

Figure 2. Forest Zoning for Restoration in Mexico.

\section{RESULTS AND DISGUSSION}

\section{Degraded areas and priority areas for restoration plantations}

With respect to the degradation of EZs, three zones presented the largest area $(>18000$ ha), 32 smaller areas (<8000 ha) and six intermediate areas (8 to 18000 ha) (Figure 3). The results show that the north of the country has the largest areas of forest land degradation, which implies that the production of plants of the analyzed species or others, such as, for example, P. oocarpa Schiede ex Schltdl. (VII.1), or P. durangensis Martinez (III.2) (Flores et al., 2019) for tree planting in large areas for restoration purposes. 
With respect to the intermediate surface areas of degradation distributed in the north, center and south of the country (Figure 3), it is necessary to continue with the use of pinaceae that have already been established in plantations or consider other species, using P. maximinoi H. E. Moore (XII.3), P. lawesonii Roezl ex Gordon (XII.2) or P. leiophylla Schiede ex Schltdl. et Cham. (X.3), which is more effective if the number of forest nurseries in each EZ is considered, since it determines the amount of seedlings to be used (Flores et al., in press). For areas with less degraded surface, located in the rest of the country (Figure 3), it should also be considered to expand the species to be used in nurseries that are commonly used for restoration, as well as other species, such as P. leiophylla, P. maximartinezii Rzed. or P. teocote Schiede ex Schltdl. et Cham. in IX.1).

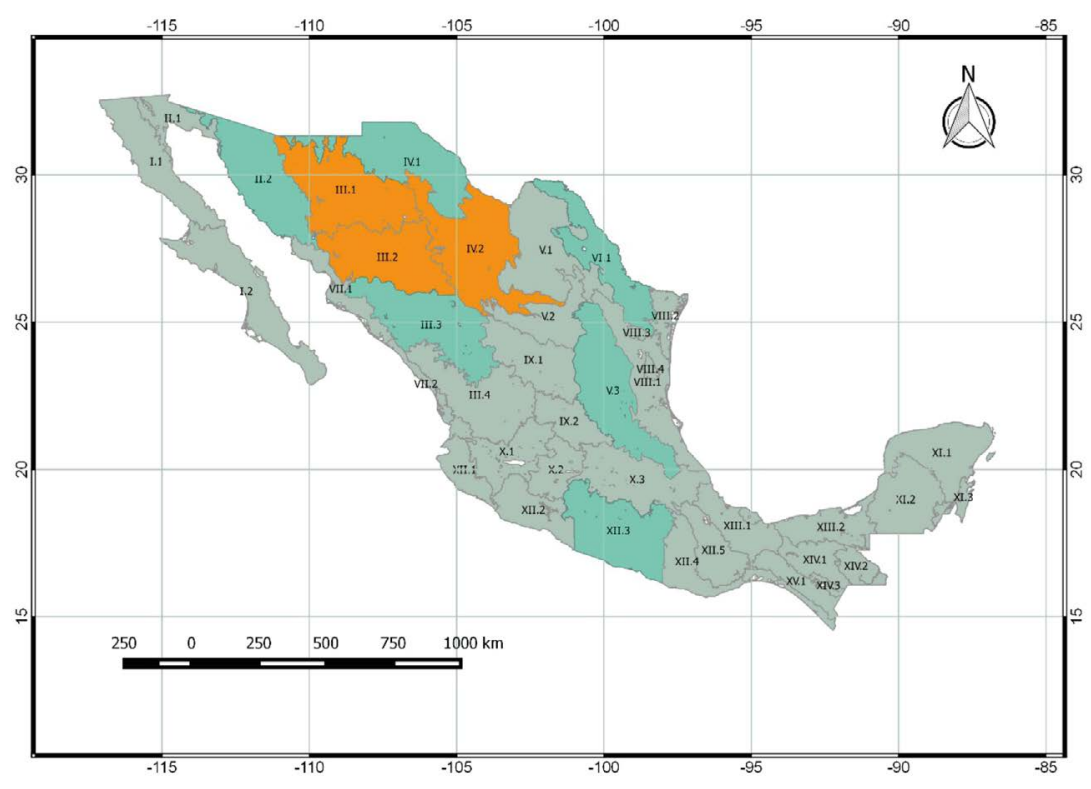

Figure 3. Areas of forest land degradation in the EZs: $>18000$ ha (orange color), 8 to 18000 ha (green color) and $<8000$ ha (gray color).

The estimation of priority and viable degraded areas to carry out plantations for restoration purposes in degraded land type III.C presented less surface (19 618.53 ha) than III.D (126 706.95 ha), so an effective strategy would be aimed at recovering first the areas with less degree of erosion (III.D). On the other hand, seven EZs with degradation type III.C had $75.69 \%$ (14 849.01 ha) of the surface and 26 zones only $24.31 \%$ (4 $769.52 \mathrm{ha}$ ), while six EZs with degradation type III.D covered 71.43\% (90 511.85 ha) and 32 zones 28.57\% (36 195.10 ha) (Table 1).

In relation to the degraded areas of forest land in the EZs, areas with degradation type III.C presented lower percentages (33.33 to $0.00 \%$ ) compared to areas with III.D $(96.28$ to $0.10 \%$ ) (Table 1 ). Consequently, the same characteristic was presented when the degradation of each EZ was analyzed with respect to the total degraded area of all types (III.A to III.E) of the country; that is, III.C covered lower percentages (11.76 to $0.00 \%)$ than III.D (11.76 to $0.00 \%$ ) (Table 1). When considering together areas with degradation 
Table 1. Areas with medium (III.C type) and low degradation (III.D type) for forest land in EZ.

\begin{tabular}{|c|c|c|c|c|}
\hline $\mathbf{E Z}$ & $\begin{array}{c}\text { Type of } \\
\text { degradation }\end{array}$ & Area (ha) & $\begin{array}{c}\text { Percentage of } \\
\text { degradation in EZ }\end{array}$ & $\begin{array}{c}\text { Percentage of } \\
\text { degradation in the } \\
\text { country }\end{array}$ \\
\hline I. 1 & III D & 861.11 & 97.04 & 0.44 \\
\hline $\mathrm{I} .2$ & III D & 435.88 & 84.50 & 0.22 \\
\hline II. 1 & III D & 125.59 & 99.80 & 0.06 \\
\hline II.2 & III D & $12,596.90$ & 94.25 & 6.46 \\
\hline III.1 & III C & $2,991.40$ & 12.71 & 1.53 \\
\hline III.1 & III D & $20,287.40$ & 86.21 & 10.40 \\
\hline III.2 & III C & $4,554.13$ & 24.60 & 2.33 \\
\hline III.2 & III D & $12,097.31$ & 65.35 & 6.20 \\
\hline III. 3 & III C & $1,089.64$ & 10.01 & 0.56 \\
\hline III. 3 & III D & $9,132.12$ & 83.89 & 4.68 \\
\hline III. 4 & III C & 458.33 & 9.17 & 0.23 \\
\hline III. 4 & III D & $2,555.43$ & 51.13 & 1.31 \\
\hline IV.1 & III C & 508.67 & 4.03 & 0.26 \\
\hline IV.1 & III D & $12,014.46$ & 95.15 & 6.16 \\
\hline IV.2 & III C & $1,717.23$ & 6.70 & 0.88 \\
\hline IV.2 & III D & $22,948.89$ & 89.58 & 11.76 \\
\hline IX.1 & III C & 739.69 & 16.29 & 0.38 \\
\hline IX.1 & III D & $1,238.91$ & 27.29 & 0.63 \\
\hline IX.2 & III C & 412.49 & 8.51 & 0.21 \\
\hline IX.2 & III D & 305.51 & 6.31 & 0.16 \\
\hline V.1 & III D & $7,374.29$ & 94.87 & 3.78 \\
\hline $\mathrm{V} .2$ & III C & 771.59 & 18.34 & 0.40 \\
\hline $\mathrm{V} .2$ & III D & $3,136.42$ & 74.56 & 1.61 \\
\hline V.3 & III C & $2,676.32$ & 29.89 & 1.37 \\
\hline V.3 & III D & $1,873.98$ & 20.93 & 0.96 \\
\hline VI.1 & III C & 943.26 & 8.04 & 0.48 \\
\hline VI.1 & III D & $10,566.89$ & 90.10 & 5.42 \\
\hline VII.1 & III D & 944.81 & 96.28 & 0.48 \\
\hline VII.2 & III G & 20.99 & 8.53 & 0.01 \\
\hline VII.2 & III D & 24.98 & 10.15 & 0.01 \\
\hline VIII.1 & III C & 114.44 & 3.00 & 0.06 \\
\hline VIII.1 & III D & $2,768.62$ & 72.48 & 1.42 \\
\hline VIII.2 & III C & 66.77 & 11.91 & 0.03 \\
\hline VIII.2 & III D & 399.88 & 71.33 & 0.20 \\
\hline VIII.3 & III C & 59.44 & 5.32 & 0.03 \\
\hline VIII.3 & III D & $1,058.10$ & 94.63 & 0.54 \\
\hline VIII.4 & III C & 11.16 & 12.27 & 0.01 \\
\hline VIII.4 & III D & 76.20 & 83.77 & 0.04 \\
\hline
\end{tabular}


Table 1. Continued.

\begin{tabular}{|c|c|c|c|c|}
\hline $\mathbf{E Z}$ & $\begin{array}{c}\text { Type of } \\
\text { degradation }\end{array}$ & Area $($ ha) & $\begin{array}{c}\text { Percentage of } \\
\text { degradation in EZ }\end{array}$ & $\begin{array}{c}\text { Percentage of } \\
\text { degradation in the } \\
\text { country }\end{array}$ \\
\hline X.1 & III C & 59.21 & 1.78 & 0.03 \\
\hline X.1 & III D & $1,980.02$ & 59.49 & 1.01 \\
\hline $\mathrm{X} .2$ & III C & 102.60 & 8.31 & 0.05 \\
\hline $\mathrm{X} .2$ & III D & 36.22 & 2.93 & 0.02 \\
\hline X.3 & III C & 638.90 & 33.33 & 0.33 \\
\hline $\mathrm{X} .3$ & III D & 509.78 & 26.60 & 0.26 \\
\hline XI.1 & III C & 4.06 & 0.12 & 0.00 \\
\hline XI.1 & III D & 18.20 & 0.53 & 0.01 \\
\hline $\mathrm{XI} .2$ & III G & 0.83 & 0.02 & 0.00 \\
\hline XI.2 & III D & 4.12 & 0.10 & 0.00 \\
\hline XII.1 & III C & 13.10 & 1.73 & 0.01 \\
\hline XII.1 & III D & 34.68 & 4.59 & 0.02 \\
\hline XII.2 & III G & 60.82 & 1.70 & 0.03 \\
\hline XII.2 & III D & 72.21 & 2.02 & 0.04 \\
\hline XII.3 & III C & 877.03 & 8.31 & 0.45 \\
\hline XII.3 & III D & 471.20 & 4.46 & 0.24 \\
\hline XII.4 & III C & 206.59 & 9.87 & 0.11 \\
\hline XII.4 & III D & 57.30 & 2.74 & 0.03 \\
\hline XII.5 & III C & 107.90 & 18.16 & 0.06 \\
\hline XII.5 & III D & 94.03 & 15.83 & 0.05 \\
\hline XIII.1 & III G & 11.32 & 3.47 & 0.01 \\
\hline XIII.1 & III D & 199.05 & 60.92 & 0.10 \\
\hline XIII.2 & III C & 15.84 & 1.89 & 0.01 \\
\hline XIII.2 & III D & 6.25 & 0.75 & 0.00 \\
\hline XIII.3 & III D & 117.00 & 99.60 & 0.06 \\
\hline XIV.1 & III C & 273.67 & 26.16 & 0.14 \\
\hline XIV.1 & III D & 141.18 & 13.50 & 0.07 \\
\hline XIV.2 & III G & 9.05 & 6.18 & 0.00 \\
\hline XIV.2 & III D & 95.64 & 65.27 & 0.05 \\
\hline XIV.3 & III G & 1.38 & 4.25 & 0.00 \\
\hline XV.1 & III C & 84.89 & 32.94 & 0.04 \\
\hline XV.1 & III D & 46.39 & 18.00 & 0.02 \\
\hline XV.2 & III G & 15.79 & 28.91 & 0.01 \\
\hline
\end{tabular}

type III.C and III.D in the EZs, it is possible to group three groups for restoration work, i.e., 23 areas $<1,000$ ha, 10 areas between 1,000 and 10,000 ha, and seven areas $>10,000$ ha (Figure 4). 


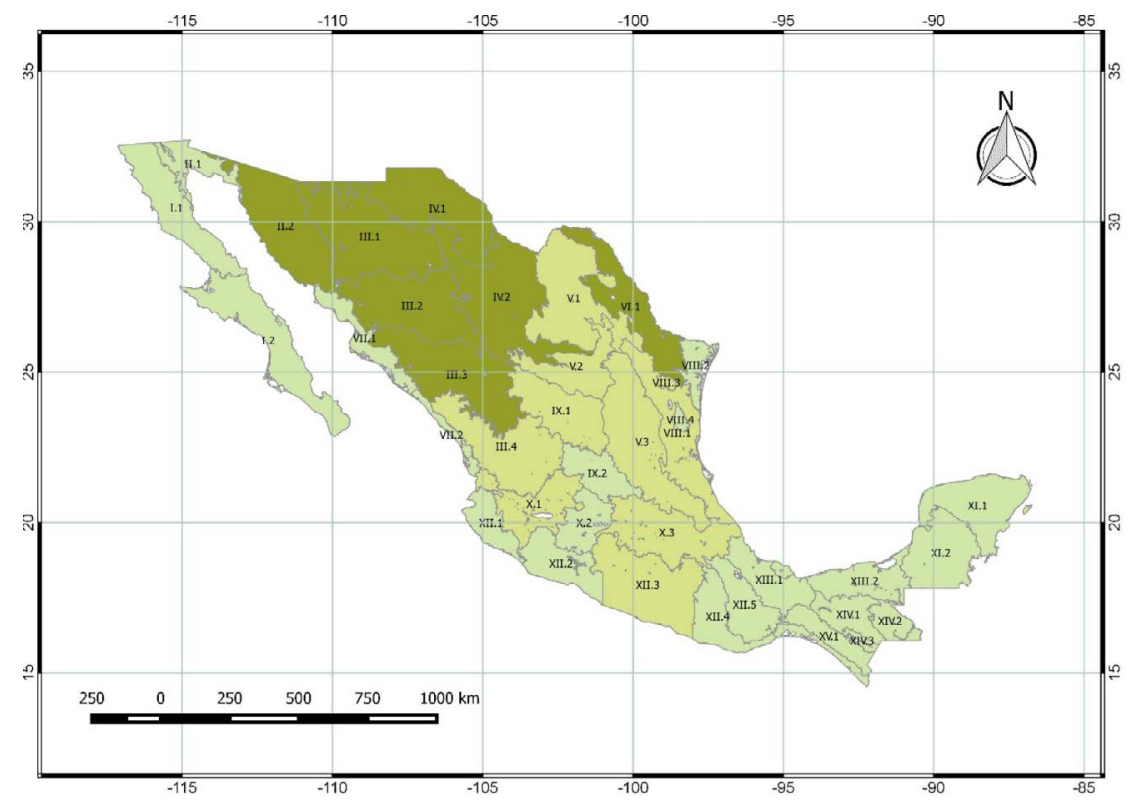

Figure 4. Type III.C and III.D degradation surfaces of EZ for restoration: > 10000 ha (dark green color), 1000 to 10000 ha (yellow color), <1000 ha (light green color).

There are species with good restoration capacity and a high percentage of survival that can be employed in sites with degradation type III.C and III.D in some local regions of Mexico, for example, in the Monarch Butterfly Biosphere Reserve (Honey-Rosés et al., 2018). Juniperus flaccida Schltdl is a conifer that grows in degraded soils and is drought resistant, with good wood quality and rot resistance (Newton \& Tejedor, 2011; Willson $e t$ al., 2008). Some pine species have good potential for restoration, e.g. P. pseudostrobus Lindl.; P. engelmannii Carrière, P. montezumae Lamb., P. greggii Engelm., P. arizonica (Engelm.) Shaw, and $P$. durangensis (Flores et al., 2019), which should be taken into account during the implementation of strategies aimed at reducing forest soil loss. There are examples of good survival in pines during restoration works, such as: P. cembroides Zucc. 90\% (GómezRomero et al., 2012), P. pseudostrobus 86\% (Gómez-Romero et al., 2013), P. devoniana Lindl. 80\% (Gómez-Romero et al., 2012) and P. montezumae 60\% (Blanco-García et al., 2008), which could be used in the EZs. In this regard, it is necessary to promote the use of these pines, but above all to carry out restoration evaluations on species for which there is still no information reported.

\section{Pinus plantations within their natural range}

In Mexico, an annual average of 2382.09 ha of pine has been established during 2016 to 2018 using 17 species: P. ayacahuite Ehrenb. ex Schltdl., P. arizonica, P. caribaea Morelet, P. cembroides, P. chiapensis (Martinez) Andresen, P. cooperi Blanco, P. devoniana, P. douglasiana Martinez, P. eldarica Medw, P. engelmannii, P. greggii, P. hartwegii Lindl., P. leiophylla, P. montezumae, P. oocarpa, P. patula Schiede ex Schltdl. et Cham. and $P$. pseudostrobus (Table 2). Most of the conifers used for plantation establishment have been within their natural range, with the exception of four species: $P$. greggii, $P$. ayacahuite, $P$. caribea and P. cembroides (Table 2). 
Table 2. Areas planted with pine and its location within the natural distribution range of the species by state.

\begin{tabular}{|c|c|c|c|c|c|c|}
\hline \multirow{2}{*}{ State } & \multirow{2}{*}{ Species } & \multicolumn{4}{|c|}{ Planted Area $(\text { ha })^{\mathrm{q}}$} & \multirow{2}{*}{ Location* } \\
\hline & & 2016 & 2017 & 2018 & Mean & \\
\hline \multirow{2}{*}{ Ags } & P. greggii & 0.00 & 0.00 & 67.03 & 22.34 & No \\
\hline & Subtotal & 0.00 & 0.00 & 67.03 & 22.34 & \\
\hline \multirow{4}{*}{ Chih } & P. arizonica & 0.00 & 70.00 & 0.00 & 23.33 & Yes \\
\hline & P. eldarica & 8.00 & 0.00 & 0.00 & 2.67 & - \\
\hline & P. engelmannii & 155.00 & 14.00 & 0.00 & 56.33 & Yes \\
\hline & Subtotal & 163.00 & 84.00 & 0.00 & 82.33 & \\
\hline \multirow{4}{*}{ Dgo } & P. cooperi & 3.10 & 25.00 & 0.00 & 9.37 & - \\
\hline & P. engelmannii & 148.00 & 75.50 & 158.00 & 127.17 & Yes \\
\hline & P. greggii & 161.90 & 293.90 & 79.00 & 178.27 & Yes \\
\hline & Subtotal & 313.00 & 394.40 & 237.00 & 314.80 & \\
\hline \multirow{7}{*}{$\begin{array}{l}\text { Edo } \\
\text { Mex }\end{array}$} & P. ayacahuite & 78.90 & 19.75 & 12.62 & 37.09 & No \\
\hline & P. greggii & 77.70 & 127.21 & 71.89 & 92.27 & Yes \\
\hline & P. hartweggii & 170.40 & 0.00 & 0.00 & 56.80 & Yes \\
\hline & P. montezumae & 173.10 & 80.16 & 0.00 & 84.42 & Yes \\
\hline & P. patula & 158.67 & 42.75 & 28.51 & 76.64 & Yes \\
\hline & P. pseudostrobus & 86.75 & 42.40 & 2.48 & 43.88 & Yes \\
\hline & Subtotal & 745.52 & 312.27 & 115.50 & 391.10 & \\
\hline \multirow{8}{*}{ Mich } & P. devoniana & 138.21 & 6.40 & 0.00 & 48.20 & Yes \\
\hline & P. douglasiana & 0.00 & 0.00 & 44.00 & 14.67 & Yes \\
\hline & P. greggii & 124.61 & 71.00 & 2.19 & 65.93 & Yes \\
\hline & P. leiophylla & 244.50 & 82.23 & 0.00 & 108.91 & Yes \\
\hline & P. oocarpa & 38.20 & 38.70 & 18.00 & 31.63 & Yes \\
\hline & P. patula & 40.95 & 0.00 & 0.00 & 13.65 & Yes \\
\hline & P. pseudostrobus & 29.00 & 66.90 & 23.86 & 39.92 & Yes \\
\hline & Subtotal & 615.47 & 265.23 & 88.05 & 322.92 & \\
\hline \multirow{2}{*}{ Nay } & P. douglasiana & 0.00 & 42.00 & 0.00 & 14.00 & Yes \\
\hline & \begin{tabular}{|l|} 
Subtotal \\
\end{tabular} & 0.00 & 42.00 & 0.00 & 14.00 & \\
\hline \multirow{3}{*}{ Oax } & P. pseudostrobus & 75.00 & 75.00 & 177.00 & 109.00 & Yes \\
\hline & P. patula & 40.86 & 73.91 & 0.00 & 38.26 & Yes \\
\hline & Subtotal & 115.86 & 148.91 & 177.00 & 147.26 & \\
\hline \multirow{7}{*}{ Pue } & P. ayacahuite & 0.00 & 5.53 & 15.00 & 6.84 & Yes \\
\hline & P. cembroides & 87.91 & 0.00 & 0.00 & 29.30 & - \\
\hline & P. greggii & 143.54 & 31.12 & 20.62 & 65.09 & Yes \\
\hline & P. montezumae & 230.34 & 6.00 & 8.69 & 81.68 & Yes \\
\hline & P. patula & 286.84 & 137.90 & 32.77 & 152.50 & Yes \\
\hline & P. pseudostrobus & 63.62 & 20.46 & 82.13 & 55.40 & Yes \\
\hline & Subtotal & 812.25 & 201.01 & 159.21 & 390.82 & \\
\hline \multirow{2}{*}{ Tab } & P. caribaea & 303.10 & 331.82 & 262.78 & 299.23 & No \\
\hline & Subtotal & 303.10 & 331.82 & 262.78 & 299.23 & \\
\hline \multirow{6}{*}{ Ver } & P. ayacahuite & 0.00 & 5.00 & 0.00 & 1.67 & Yes \\
\hline & P. caribaea & 790.46 & 0.00 & 265.58 & 352.01 & No \\
\hline & P. chiapensis & 20.00 & 26.30 & 0.00 & 15.43 & - \\
\hline & P. montezumae & 5.00 & 0.00 & 0.00 & 1.67 & Yes \\
\hline & P. patula & 0.00 & 13.00 & 0.00 & 4.33 & Yes \\
\hline & Subtotal & 815.46 & 44.30 & 265.58 & 375.11 & \\
\hline \multirow{4}{*}{ Zac } & P. cembroides & 41.53 & 0.00 & 0.00 & 13.84 & No \\
\hline & P. devoniana & 0.00 & 25.00 & 0.00 & 8.33 & Yes \\
\hline & \begin{tabular}{|l|} 
Subtotal \\
\end{tabular} & 41.53 & 25.00 & 0.00 & 22.18 & \\
\hline & Total & 3925.19 & 1848.94 & 1372.15 & 2382.09 & \\
\hline
\end{tabular}

Base on Conafor's information. * Within the natural range of the species. 
The use of species in places that are not within their natural distribution range is considered a serious problem because trees are being planted that will not be able to withstand adverse conditions (low precipitation, frost, drought, high temperature) in regions where they do not come from, for example, P. hartwegii presents more than $70 \%$ mortality due to water stress (Salas-González \& Franco, 2001). Under this condition, plants will present adaptation difficulties and will decrease the restoration potential that is intended to take advantage of them, e.g. plantations of $P$. greggii that have been established in the state of Durango present health and mortality problems, significantly reducing their potential (J. Á. Prieto-Ruíz, personal communication, October 23, 2019).

\section{CONGLUSIONS}

For Mexico, the north of the country has the largest areas with forest land degradation, while the center, north and south have areas with medium and low degradation. Restoration of priority degraded areas can be initiated in lands with medium (III.C) and low (III.D) degradation, because they could be restored in a short time: $23 \mathrm{EZs}(<1000 \mathrm{ha})$, ten EZs (1000 to 8000 ha) and seven EZs (>10 000 ha). An effective strategy for the restoration of degraded areas should be aimed at restoring the less eroded areas first (III.D). The average area planted from 2016 to 2018 was 2382.09 ha for pine forest plantations, although this depended on the species and year. In general, the species have been established in places that are within their natural distribution range; however, in some of them such as P. greggii, P. ayacahuite, $P$. caribea and $P$. cembroides were planted outside this, which could lead to plant adaptation problems.

\section{ACKNOWLEDGMENTS}

The authors would like to thank CONAFOR for providing the data and information cited in the paper.

\section{REFERENGES}

Barbier, E. B., \& Hochard, J. P. (2016). Does land degradation increase poverty in developing countries? PLoS ONE, 11(5), 13-15. Doi: 10.1371/ journal.pone.0152973

Blanco-García, A., Sáenz-Romero, C., Alvarado-Sosa, P., \& Lindig-Cisneros, R. (2008). Native pine species performance in response to age at planting and mulching in a site affected by volcanic ash deposition. New Forests, 36(3), 299-305. Doi: 10.1007/s11056-008-9101-z

Boer, B. W., Ginzky, H., \& Heuser, I. L. (2017). International soil protection law: History, concepts and latest developments. In H. Ginzky, I. L. Heuser, T. Qin, O. G. Ruppel, \& P. Wegerdt (Eds.), International Yearbook of Soil Law and Policy 2016 (pp. 49-72). Springer International Publishing. Doi: 10.1007/978-3-319-42508-5_7

Comisión Nacional Forestal. (2014). México cuenta con 270 mil hectáreas de Plantaciones Forestales Comerciales. Disponible en: http://www. conafor.gob.mx:8080/documentos/docs/7/5752México cuenta con 270 mil hectáreas de Plantaciones Forestales Comerciales.pdf

Comisión Nacional Forestal. (2016). Manual para el establecimiento de unidades productoras de germoplasma forestal. Conafor. Disponible en : http:// www.conafor.gob.mx:8080/documentos/ver.aspx?articulo=1290\&grupo=19

Comisión Nacional Forestal. (2017a). Inventario Nacional Forestal y de Suelo (INFyS) 2013-2014, colección de 32 tomos. Disponible en: http:// www.conafor.gob.mx/innovacion_forestal/?p=2908

Comisión Nacional Forestal. (2017b). Zonificación Forestal. Disponible en: https://www.cnf.gob.mx:8443/snif/portal/zonificacion

Couturier, S., Manuel, J., \& Kolb, M. (2012). Measuring tropical deforestation with error margins: A method for REDD monitoring in SouthEastern Mexico. In P. Sudarshana, M. Nageswara-Rao, \& J. R. Soneji (Eds.), Tropical Forests (pp. 269-296). InTech. Doi: 10.5772/31523

Food and Agriculture Organization. (2001). FRA 2000: Global ecological zoning for the global forest Resources assessment 2000. Final Report. http://www. fao.org/3/ad652e/ad652e00.htm

Flores, A., Muñoz-Gutiérrez, L., Velasco García, M. V., \& Zamora Morales, B. P. (2018). Desarrollo y perspectivas de investigación en Plantaciones y Sistemas Agroforestales. In M. C. Zamora-Martínez, F. T. A. García C., \& C. Méndez E. (Eds.), 60 años de la investigación forestal en Coyoacán (pp. 166-219). Cenid-Comef, INIFAP. 
Flores, A., Pineda Ojeda, T., \& Flores Ayala, E. (2019). Potencial de reforestación de seis especies de pino para la restauración de zonas degradadas. Revista Mexicana de Ciencias Forestales, 10(55), 171-179. Doi:10.29298/rmcf.v10i55.604

Flores, A., Velasco-García, M. V., Muñoz-Gutiérrez, L., Martínez-Trinidad, T., Gómez-Cárdenas, M., \& Castillo Martínez, G. R. (2018). Especies arbóreas para conservar la biodiversidad en zonas urbanas. Mitigación del Daño Ambiental Agroalimentario y Forestal de México, 4(5), $136-151$.

Flores Flores, C., López-Upton, J., \& Valencia Manzo, S. (2014). Manual técnico para el establecimiento de ensayos de procedencias y progenies. Conafor. Disponible en: http://www.conafor.gob.mx:8080/documentos/docs/19/0Manual\%20Te\%CC\%81 cnico\%20para\%20el\%20 Establecimiento\%20de\%20Ensayos.pdf

Galicia, L., Gómez-Mendoza, L., \& Magaña, V. (2015). Climate change impacts and adaptation strategies in temperate forests in Central Mexico: a participatory approach. Mitigation and Adaptation Strategies for Global Change, 20(1), 21-42. Doi: 10.1007/s11027-013-9477-8

Gómez-Romero, M., Soto-Correa, J. C., Blanco-García, J. A., Sáenz-Romero, C., Villegas, J., \& Lindig-Cisneros, R. (2012). Estudio de especies de pino para restauración de sitios degradados. Agrociencia, 46(8), 795-807.

Gómez-Romero, M., Villegas, J., Sáenz-Romero, C., \& Lindig-Cisneros, R. (2013). Efecto de la micorrización en el establecimiento de Pinus pseudostrobus en cárcavas. Madera y Bosques, 19(3), 51-63. Doi: 10.21829/myb.2013.193327

Gorte, R. W., \& Sheikh, P. A. (2010). Deforestation and climate change. Congressional Research Service report. http://forestindustries.eu/sites/default/ files/userfiles/1file/R41144.pdf

Honey-Rosés, J., Maurer, M., Ramírez, M. I., \& Corbera, E. (2018). Quantifying active and passive restoration in Central Mexico from 19862012: assessing the evidence of a forest transition. Restoration Ecology, 26(6), 1180-1189. Doi: 10.1111/rec.12703

Newton, A. C., \& Tejedor, N. (2011). Principles and practice of forest landscape restoration: Case studies from the drylands of Latin. IUCN. Disponible en: http://eprints.bournemouth.ac.uk/18270/2/2011-017.pdf

QGIS Development Team. (2015). QGIS Geographic Information System (Version 2.8.7) [Computer software]. Open Source Geospatial Foundation Project. Disponible en: https://qgis.org/en/site/

Salas-González, R., \& Franco, M. (2001). Seedlings performance of two conifer species in disturbed alpine areas in Central Mexico. Silva Lusitana, 9(2), 143-159.

SEMARNAT. (2015). Inventario estatal forestal y de suelos - Estado de México 2014. SEMARNAT. Disponible en : https://www.sema.gob.mx/SRN/ DESCARGABLES/Metodologia_Zonificacion_Forestal_IEFYS.pdf

Stein, S. M., McRoberts, R. E., Alig, R. J., Nelson, M. D., Theobald, D. M., Eley, M., Dechter, M., \& Carr, M. (2005). Forests on the edge: Housing development on America's private forests. USDA Forest Service.

Wallace, J., Aquilué, N., Archambault, C., Carpentier, S., Francoeur, X., Greffard, M.-H., Laforest, I., Galicia, L., \& Messier, C. (2015). Present forest management structures and policies in temperate forests of Mexico: challenges and prospects for unique tree species assemblages. The Forestry Chronicle, 91(03), 306-317. Doi: 10.5558/tfc2015-052

Willson, C. J., Manos, P. S., \& Jackson, R. B. (2008). Hydraulic traits are influenced by phylogenetic history in the drought-resistant, invasive genus Juniperus (Cupressaceae). American Journal of Botany, 95(3), 299-314. Doi: 10.3732/ajb.95.3.299 